\title{
SE SUPRIMEN NORMAS DE DESIGUALDAD DE TRATO A LAS PERSONAS POR RAZON DE SEXO Y OTROS MOTIVOS.
}

\section{LAS MUJERES CASADAS PODRAN RECUPERAR SU VECINDAD CIVIL.}

\author{
Por José Mellado Manzano. Granada.
}

Abogado.

El día siete de este mes entra en vigor una ley por la que desaparecen desigualdades legales entre hombres y mujer, modificándose trece artículos del Código Civil, que indicaremos a continuación, adaptando dichos preceptos al principio constitucional de igualdad, y que afectan a las materias siguientes.

Matrimonio. Dentro de las normas de derecho internacional privado del Código Civil, queda modificado su artículo 9, apartados 2 y 3 , que versan sobre las normas aplicables a los cónyuges y a sus bienes, en el sentido de que los efectos del matrimonio se regirán por la ley personal o correspondiente a su nacionalidad, común a ambos cónyuges al tiempo de contraer su matrimonio, y en su defecto, por la ley personal o residencia habitual de cualquiera de ellos, elegida por los dos, mediante documento auténtico, por ejemplo escritura notarial, antes de celebrarse el matrimonio, suprimiéndose lo hasta ahora vigente de que sería la ley nacional del marido al tiempo de la celebración; y a falta de dicha elección, por la ley de la residencia habitual común inmediata posterior a la celebración, y finalmente, a falta de dicha residencia, por la del lugar de celebración del matrimonio.

En cuanto a la separación y al divorcio, se mantiene como norma la ley nacional que establece el propio Código Civil (art.107).

Las capitulaciones, o pactos sobre los bienes entre cónyuges, se regirán sucesivamente por la ley que regula los efectos del matrimonio antes referida, o en su defecto, la nacionalidad o residencia habitual de cualquiera de los esposos al tiempo de otorgarse las capitulaciones.

\section{Adopción.}

Manteniéndose su regulación dada por la ley 21 de 1987, el apartado 5 del citado art. 9 del Código Civil, tiene una nueva redacción, disponiéndose que la adopción constituida por Juez español, en cuanto a sus requisitos se rige por la ley española, si bien ha de respetarse la ley nacional de la persona que va a ser adoptada -adop- 
tande en lo atinente a su capacidad y consentimientos necesarios, cuando la residencia habitual de éste la tuviera fuera de España, o aún residiendo en España cuando no adquiera la nacionalidad española por la adopción.

\section{Sucesión por causa de muerte. Derechos del viudo o viuda.}

Se sigue aplicando la regulación actual, añadiendose, en el apartado 8 del art. 9 del Código, un último párrafo, disponiéndose que los derechos del cónyuge sobreviviente -viudo o viuda- se regirán por la misma ley que regule los efectos del matrimonio, respetándose las legítimas de los hijos o descendientes.

\section{Vecindad civil, sujeción al Derecho común o foral.}

Sobre la vecindad civil o pertenencia a una Comunidad regional de España, se modifica el atr. 14, distinguiéndose, de una parte las normas respecto a los hijos y adoptados, y de otra las referentes a la mujer casada. Así, en cuanto a los primeros, se establece que la vecindad civil en territorio de Derecho común o especial (foral), la tienen los nacidos o adoptados, de padres que tengan tal vecindad, pero, si al nacer el hijo o ser adoptado, los padres tuvieran distinta vecindad civil, el hijo tendrá la que corresponda a áquel de los dos respecto del cuál la filiación haya sido determinada antes, o en su defecto, la del lugar del nacimiento, o en último término, la vecindad de Derecho común. Sin embargo, en tales casos, dentro de los seis meses siguientes al nacimiento o a la adopción, los padres podrán atribuir la vecindad civil de cualquiera de ellos. Por su parte, el hijo desde que cumpla los 14 años y hasta un año después de su emancipación-ordinariamente a los 19-, tiene derecho a optar por la vecindad civil del lugar de su nacimiento o por la última vecindad de cualquiera de sus padres.

\section{La mujer al casarse no pierde su propia vecindad.}

Se ha suprimido la disposición de que "la mujer casada seguirá la condición del marido", pues se da también nueva redacción al apartado 4 del art. 14 del Código, diciendo que "el matrimonio no altera la vecindad civil, si bien cualquiera de los cónyuges, no separados, puede optar por la vecindad civil del otro".

\section{Conflictos de leyes dentro del territorio nacional.}

Se mantiene la normativa del art. 16 del Código, agregándose al final del mismo un tercer párrafo, que viene a preceptuar que los efec- 
tos civiles del matrimonio entre españoles se regularán por la ley española que resulte aplicable, según lo establecido en el art. 9 antes aludido, o en su defecto, se aplicará el régimen de separación de bienes si hubiere de regir un sistema de separación.

\section{Las escrituras de los bienes de herencias.}

¿A quién se entregan, al hombre o a la mujer ?.

Cuando en las particiones de herencia, una misma escritura comprende varias fincas o una finca sin dividir, dicha escritura, en el caso de no existir ningún heredero mayor interesado, es decir, cuando el interés fuere igual entre todos los coherederos, se entregará a la persona que se designe por todos, o en su defecto, la que resulte designada en suerte, pero no precisamente al varón, como se decia hasta ahora. (art.1.066).

\section{¿La mujer era cobarde?}

En relación a la validez de los contratos, se suprime la mención al sexo,que contiene el atr. 1.267, cuando al hablar de la intimidación a un contratante el temor de sufrir un mal inminente y grave, dice que para calificar tal intimidación "debe atenderse a la edad, al sexo, y a la condición de la persona", desapareciendo, pues, desde ahora la referencia al sexo, mención que suponía que la mujer era más débil que el hombre.

\section{A los hijos mayores, también alimentos.}

Mientras vivan en el domicilio familiar los hijos mayores de 18 años o emancipados sin ingresos propios, tendrán también derecho a recibir alimentos por parte de sus padres, novedad que comporta el párrafo añadido al art.93.

\section{¿A quién se entregan los hijos menores de 7 años?.}

Se modifica el art. 159, que establece a cuál de los cónyuges separados se han de entregar los hijos menores de siete años, cuando no haya acuerdo entre los padres, fijándose que será, no necesariamente a la madre, como se decia hasta ahora, sino al progenitor que designe el Juez, oyendo antes a los hijos que tuvieren suficiente juicio.

\section{Sustituciones de palabras.}

La de "honra" por "honor" y la de "mujer" por la de "cónyuge", al regular -art.648- las causas de revocación de las donaciones. Y la de 
150

"esposa" por "cónyuge",al referirse a los créditos preferentes art.1.924- y cuando se prohibe al notario autorizar testamentos en los que resulte beneficiado él o "su esposa", palabra ésta reemplazada por la más lógica de "cónyuge", que viene a reconocer la realidad por la más lógica de "cónyuge", que viene a reconocer la realidad actual de la existencia de mujeres notarios.

\section{El adulterio y la prostitución.}

Se suprimen como causas de desheredación tanto el haber cometido adulterio con el cónyuge del testador - art. 352- , como el haber entregado la hija o nieta del testador a la prostitución - 853-,disposiciones éstas que podrían estimarse desacertadas.

Por último, resaltar que la ley concede el plazo de un año, desde el 18 de octubre del presente, para que las mujeres casadas, que por seguir la condición del marido perdieron su vecindad, puedan recuperarla, si así lo desean. 